\title{
THE IMPACT OF FINANCIAL AUDIT ON THE BALANCE OF AN ENTERPRISE - RESULTS OF EMPIRICAL RESEARCH
}

\begin{abstract}
The article discusses issues related to the impact of financial audit in building a reliable image of the economic unit after the audit of the financial statements. The aim of the article is to illustrate the analysis of audit documentation in the area of assets and liabilities conducted for the financial years 2012-2014, during which the information contained in the first version of the financial statements was compared with information from the final version, based on which the auditor could issue an opinion together with the report. As a result of research, among others such conclusion was made that financial revision still had a significant impact on improving the reliability of financial statements and is necessary to secure the functioning of business entities on the market. The research methods used in the article are: comparative analysis of audit documentation, and desk research.
\end{abstract}

Keywords: audit of financial statements, balance sheet, assets, liabilities.

\section{INTRODUCTION}

The financial report is for the receivers - especially the outward ones - the essential source of information about the functioning of a given economic unit and what results is gets in a given period of time of the report. Nowadays, when the globalisation of working and result-pressure can be observed, there may be a danger of "beautifying" of the financial reports by the people responsible for it. It could be assumed that the most sensitive part is the financial result and composing it revenues and costs, but this is not case, as the field affected alongside is the balance sheet and assets and liabilities. The balance sheet is the pert of the report being analysed by the stakeholders, when willing to make a rational decision about investing or managing a given economic unit.

That is why the financial report which was made by an unbiased and independent expert auditor builds much more confidence and trust. This concerns not only the outward receivers but also the inward stakeholders giving them information that the data included do not contain errors or abnormalities which make the image of the economic unit unreliable. An expert auditor while carrying out financial revision verifies, among others, assets and liabilities by employing accurate procedures of the examination, which enable him to collect sufficient evidence of the examination, on the basis of which he may issue a final product

\footnotetext{
${ }^{1}$ Agnieszka Lew, PhD, the Faculty of Management, Rzeszów University of Technology, al. Powstańców Warszawy 12, 35-959 Rzeszów; e-mail: a-lew@prz.edu.pl. ORCID: 0000-0003-0135-4890.
} 
of financial revision ${ }^{2}$ - which is the report of the examination - according to his knowledge, competence and professional scepticism and judgement ${ }^{3}$ and thus extend the reliability and accuracy of financial review. The main aim of financial revision "is to ensure the reliability of financial data presented by the market users in order to restrict the economic and investing risk" (Lew, 2016).

When making the analysis of the opinions ${ }^{4}$ issued by expert auditors after conducting studies on financial reports, it can be observed that the majority of them are impeccable. This kind of information may cause, especially in people not knowing the procedures of revision, a wrong idea that financial reports, being an integral part of those opinions, were obtained on the basis of error-free data. This kind of thinking is not appropriate as expert auditors give such opinions on the basis of changed, due to recommendations, financial reports (Compare: Andrzejewski, 2012; Lew, 2015).

The aim of this article is to present the analysis of the revision documentation on balance sheet made available by the audit group, concerning years 2012-2014 in over 150 economic units with various organisation structures and sizes, which had obligatory financial revision.

These studies were to show the analysis of the information contained in the first part of the financial report, which an expert auditor verified with the information contained in the final version of the financial report, on the basis of which he or she issued and opinion with the report. These studies were to enable collecting the appropriate evidence on confirmation of the influence of financial revision on separate parts of the balance sheet, which enabled the increase of its reliability, accuracy and quality for the stakeholders. To complete the empirical research desk research analysis was used.

\footnotetext{
2 In the article interchangeably is used the notion of ,the study of financial reports" and "financial revision. It is the reflection of literary research, carried out by the author, and which cannot be presented fully due to the length of the article, that prove that more and more authors of the subject literature claim that both notions carry the same procedure of the study and its final result- the report as well as the actions taking place after the actual study, which is the correction of the financial report advised by the expert auditor (Compare: Krzywda, 2012; Nowak, 2013).

3 The professional scepticism of an expert auditor is the critical approach of his mind and a critical assessment of the results of the study. The expert auditor is obliged to present professional assessment and scepticism while planning and proceeding the studying of the financial report. The professional judgement implies practical applying of the acquired skills, knowledge and experience in context described by accounting standards, financial revision and ethics, in order to make rational decisions about appropriate ways of acting in audit circumstances. On the basis of Kodeks etyki zawodowych księgowych Międzynarodowej Federacji Księgowych (IFAC) - Code of ethics for professional accountants, precleared in Polish language in w 2011 by International Federation of Accountants (IFAC).

4 The study carried out by PIBR took place when different laws were employed, according to which an expert auditor issued the opinion with the report on the examined financial report. Nowadays by law - instead of notions "opinion" and "report" the term "the report on the study" is used, which contains the opinion of the independent expert auditor on the studied financial report [Comp. Resolution no. 1554/33a/2017 Krajowej Rady Biegłych Rewidentów from 8 December 2017 on the standards of financial studies $(700(\mathrm{Z}), 701,705(\mathrm{Z}), 706(\mathrm{Z}), 720(\mathrm{Z}), 260(\mathrm{Z}), 570(\mathrm{Z}))$; and Resolution from 11 May 2017 about exert auditors, audit companies and public control (Dz.U. z 2017, poz. 1089].
} 


\section{THE STUDY OF THE BALANCE SHEET BY AN EXPERT AUDITOR}

The definition contained in KSRF 200 claims that "the general aims of an independent expert auditor and carrying out the study accordingly to International Standards of Research" informs that "the aim of the research is to increase the level of trust of the intended users to financial reports.

It can be accomplished by issuing the opinion by the expert auditor if the financial reports we in all crucial aspects prepared accordingly to the general assumptions of financial reporting" (National Standard of Financial Revision 200 in International Standard of Research 200, 2015). Thus, it appears to be crucial to examine by the expert auditor the credibility, reliability, validity and accuracy of presenting the assets and liabilities in the financial report.

The definition of assets contained in the Resolution on Accounting claims that it is a unit emerged in the result of past operations or events economically useful, controlled by a given economic unit, physical and non-physical property components with reliable worth, which predictably may be economically profitable (Ustawa o rachunkowości, 2019, art. 3, ust. 1, pkt 12; Fedak, 2018; Lew, Nowak [red.], 2016). In the case of liabilities in the Resolution on Accounting, there is no full definition of the liabilities category, but rather the very specific components of liabilities. The capitals are, among others, the nonreturnable input of assets put to the unit by the owner, and in case of obligations it is a duty of a person to make appropriate provisions which will decrease his or her present of future assets (Ustawa o rachunkowości, 2019, art. 3, ust. 1, pkt. 20; Fedak, 2018).

That is why the expert auditor while examining these categories of financial report should make sure if they were appropriately presented in a given group, if they really exist - by checking e.g. documents on stocktaking, if they are complete and correctly assessed, and collecting proves of the study, which will help to issue a report containing the opinion about the financial report. (Krzywda, Szafraniec, [red. Krzywda], 2012).

\section{METHODOLOGY OF CONDUCTED EMPIRICAL RESEARCH}

The aim of conducted empirical research was to examine if the financial revision, by applying appropriate procedures, enables verifying the information contained in the part of financial report where there is the balance sheet and if it influences the changes in particular groups of assets and liabilities. The analysis was made of the revision documentation of economic units for 3 subsequent years in which financial revision took place. The research was possible thanks to the revisory documents shared by the subject entitled to carry out financial revision. The data which enabled identification of a given economic unit were encoded. Analysed revision documents comprised researches conducted in years 2012-2014 and concerned:

- In year 2012, 168 subjects examined,

- In year 2013, 173 subjects examined,

- In year 2014, 189 subjects examined.

Having collected and analysed the general data on the examined financial reports, a division was made - according to its meaning for credibility of the financial report - into information more detailed and connected to the balance sheet. The categories were as follows:

- Assets in general,

- Capital assets, with non-physical values and legal and physical fixed assets, 
- Current assets, with creditors of delivery, services and money on bank accounts,

- The sum of liabilities,

- Equity capital, the profits (and losses) from recent years and profits (and losses) posttax from the current year,

- Long-term liabilities and reserves on legal benefits

- Current liabilities, credits and loans, financial liabilities of deliveries and services, taxes, duties, welfare, and settlement of accounts.

In order to present the differences in values of particular elements of the balance sheet appearing between the first version of financial report which was given to the expert auditor and the final version, the value ranges of the changes were used, which were given in Polish zloty.

As to present the consequences of actions of the expert auditor to detect the abnormalities that he noticed while studying the financial reports, they were organised into 5 ranges presenting those changes. The corrections made by the auditor aim to increase the credibility of the financial reports, that should also increase the credibility of th4e whole economic unit on the market. The ranges used to present the changes made by the expert auditor are as below:

1) To 100 thousand PLN,

2) From 100 thousand PLN to 500 thousand PLN,

3) From 500 thousand PLN to 1 M PLN,

4) From 1 M PLN to 10 M PLN,

5) Above 10 M PLN.

On verifying the documents while the conducted research it turned out that to present the changes, made on the suggestion of the expert auditors, they can be comprised in the first four ranges of money and there was not one above 10 million PLN in the financial reports made by economic units.

\subsection{The influence of financial revision on the quantity and structure of assets and liabilities presented in the balance sheet}

In the researched group of economic units in particular years it can be observed that the actions taken in the financial revision by the expert auditor caused changes in the balance sum in half of the cases, which enables to draw a conclusion that the primary financial report contained some abnormalities or did not contain crucial information and as a result did not present a reliable financial state of economic units. The number of financial reports of economic units where the expert auditor made changes in the balance sheet with the division into particular report periods is presented in picture 1 below.

From the data presented in picture 1 it can be seen that in 2012 in 86 economic units there was a change in the balance sum, which gives 51\% of all researched units. In 2013 there $44 \%$ and in $201448 \%$ of such cases.

To describe the elements of the balance, which were the reason for the change in the balance sum, a detailed analysis was made of the main groups composing the assets and liabilities of the balance sheet, that is capital assets, current assets and equity, and long-term liabilities and current liabilities.

When it comes to the correction of capital assets the changes were made in 33,75 and 35 economic units in the subsequent years of the financial revision, which gives $20 \%, 43 \%$ and $19 \%$ of changes in the researched financial reports. 


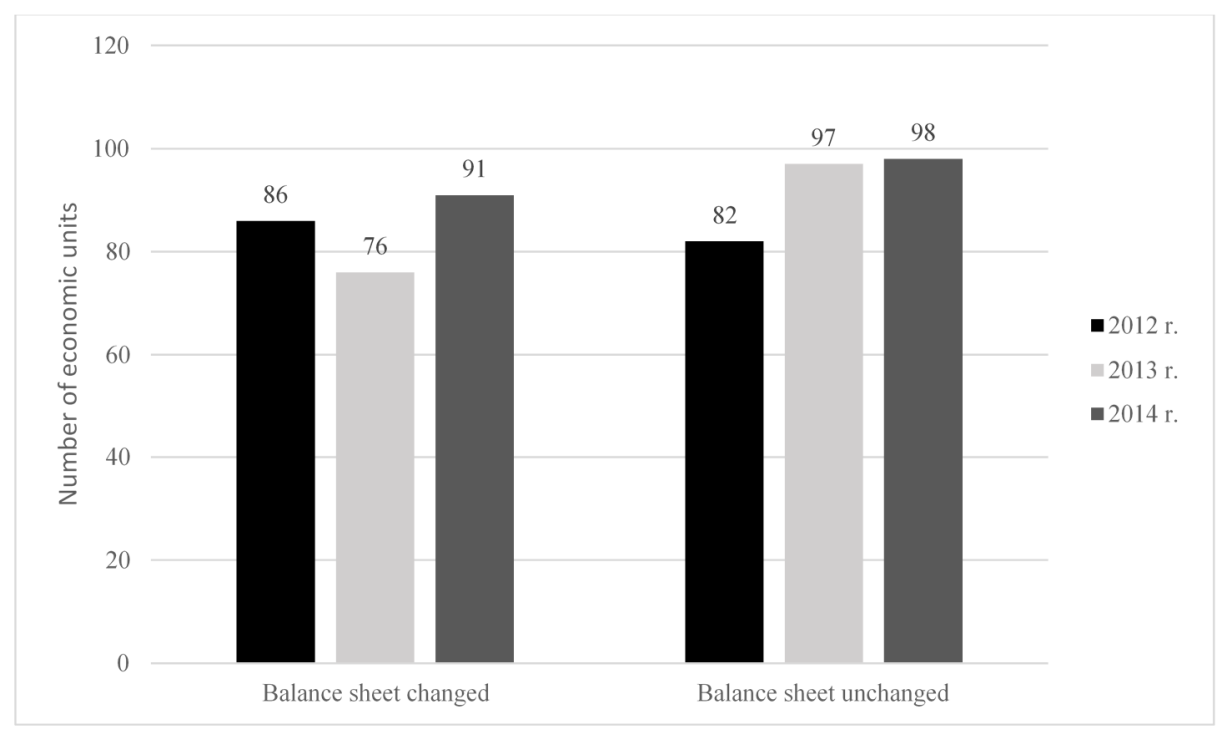

Picture 1. The structure of changes of a balance sum recommended as a result of act in financial revision in years 2012-2014

Source: Self-study.

Similar studies connected with the verification of revision documentation and the influence of financial report was carried out it Katowice centre for the current year ending in 2005. For comparison, in this study J. Pfaff reached higher results in the examined units, as in his group of modification in the structure of assets, $43 \%$ of units made changes in this category ( 97 of 223 the examined financial reports submitted to the financial revision ${ }^{5}$.

Increasing the credibility of the balance sheet in the particular periods (43\% of changes made in 2005, in comparison with 19-20\% in 2012 and 2014) is undoubtedly a result of constantly developing skills of the accountants in particular economic units. However, another motive for the decrease of recommended changes by the expert auditor may be a longer period of actions connected with financial revision in the researched units, which strengthens the pedagogic effect of these actions. People responsible for preparing the financial reports fulfil their duties in a more competent way.

The analysis of the influence of the actions of financial revision on the financial report in the sphere of a balance sheet enables to draw a conclusion that there is its impact on building a credible image of a economic unit. On the basis of this documentation it was possible to distinguish fields where there was a necessity to introduce changes advised by the expert auditor, between the first reports and their final version. Consolidated ${ }^{6}$ profile or

\footnotetext{
5 The research made by J. Pfaff concerned the year where there was the change in law after joining the EU. Economic units had to find their way in the new, not always easy to understand, reality of being on the market in the EU which has different regulations than the ones known up till then. However, he does not exclude other reasons of such results collected by J. Pfaff (Pfaff, 2008).

${ }^{6}$ Because of the restrictions on the length of the article a detailed analysis was not made of the particular categories of assets and liabilities composing the balance sheet.
} 
sheet with corrections made in the researched units and in the particular time in the balance sheet are presented in picture 2 , and the percentage is shown in table 1 .

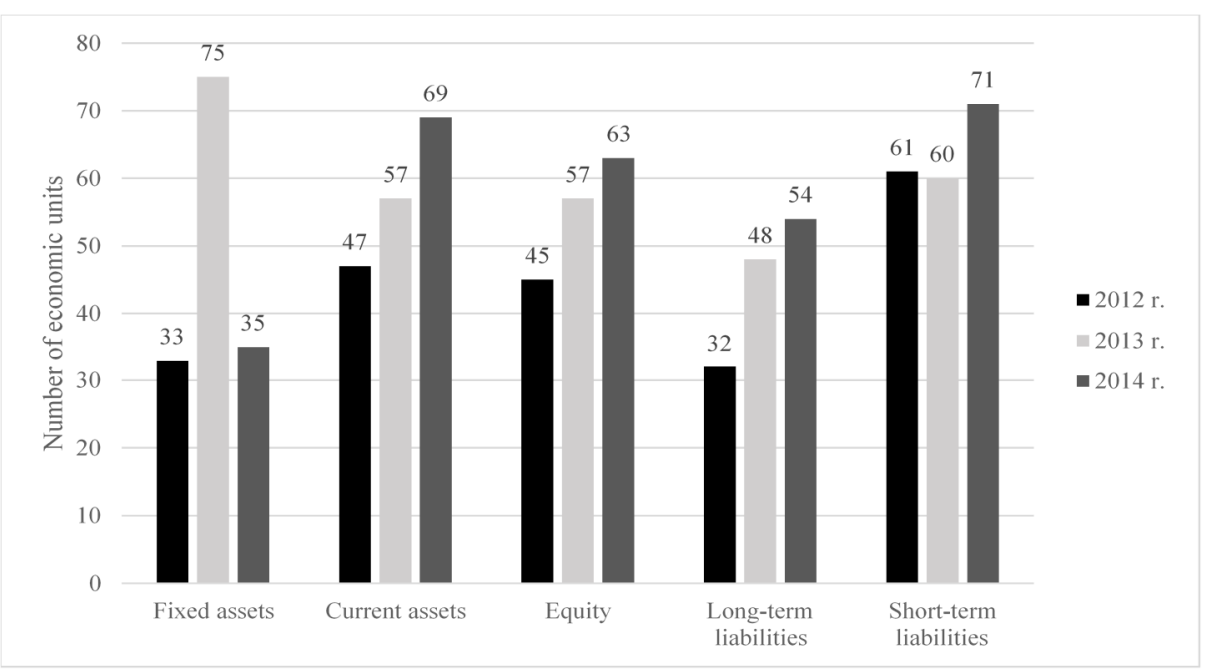

Picture 2. The structure of changes in the balance's positions, being an effect of financial revision in years 2012-2014

Source: Self-study.

Table 1. The percent structure of changes in position of balance sheet after actions taken in financial revision in years 2012-2014

\begin{tabular}{|c|c|c|c||c|c|c|}
\hline $\begin{array}{c}\text { The } \\
\text { changes }\end{array}$ & $\begin{array}{c}\text { Capital } \\
\text { assets }\end{array}$ & $\begin{array}{c}\text { Current } \\
\text { assets }\end{array}$ & Equity & $\begin{array}{c}\text { Long-term } \\
\text { liabilities }\end{array}$ & $\begin{array}{c}\text { Current } \\
\text { liabilities }\end{array}$ & $\begin{array}{c}\text { The } \\
\text { changes }\end{array}$ \\
\hline 2012 & $20 \%$ & $28 \%$ & $27 \%$ & $19 \%$ & $36 \%$ & 2012 \\
\hline 2013 & $43 \%$ & $33 \%$ & $33 \%$ & $28 \%$ & $35 \%$ & 2013 \\
\hline 2014 & $19 \%$ & $37 \%$ & $33 \%$ & $29 \%$ & $38 \%$ & 2014 \\
\hline $\begin{array}{c}\text { The } \\
\text { average of } \\
\text { a three-year } \\
\text { time }\end{array}$ & $\mathbf{2 7 \%}$ & $\mathbf{3 3 \%}$ & $\mathbf{3 1 \%}$ & $\mathbf{2 5 \%}$ & $\mathbf{3 6 \%}$ & $\begin{array}{c}\text { The } \\
\text { average of } \\
\text { a three-year } \\
\text { time }\end{array}$ \\
\hline
\end{tabular}

Source: Self-study.

In every part of the balance sheet there were changes made after conducting the actions of financial revision. Referring the number of correction made because of the expert auditors' initiative to the initial financial report, it can be concluded that over $30 \%$ (which is a considerable number) of the financial reports of the researched economic units presented their financial situation in an improper way. This may result from the fact that, part of the data presented in the report was unreliable. 
The scale of changes make in the balance sheet in percent is presented in table 1. It can be observed that these changes were made in many of researched subjects. The percent range of the corrections is the set between $19 \%$ of changes made in the capital assets in 2014 (35 researched units) and 43\% of corrections made in the same category in 2013 (75 units). The rest of the changes made in particular groups or cat4egories of the balance sheet are in the range of money in the subsequent periods of time of research. The number of corrections made by the expert auditors in the financial reports of the researched units can be declared as considerable.

Summarising the results presented in table 1 in particular periods of report in a threeyear time, it can be claimed that actions taken in financial revision carried out by the expert auditor had a significant impact on the changes made in the final version of the balance sheet when compared to its initial version in over $30 \%$ of researched economic units, which affected the increase in th $4 \mathrm{e} 4$ credibility of their financial report.

The reasons for the changes which affected the balance sheet were:

- The inappropriate presentation of lease (the lease was presented accordingly to the contract which usually concerns the operating lease that should be presented as a financial lease by law).

- The misuse of the depreciating stake of non-physical and legal values and capital assets (accordingly to tax rates).

- The lack of signatures updating the overdue payments and obligations.

- Inappropriate qualification of loans (long and short-term).

- Inappropriate values of assets and reserves from a hold-off taxes.

The changes that took place after verifying the balance sum concern mainly the set between 19 and $43 \%$ of researched units in given periods of time, the changes which were made while the examination of financial reports often are up to thousands of Polish zloty (however, th3re were also correction for over 1 million zloty).

The actions taken by expert auditors in connection with the financial revision in the sphere of assets and liabilities enabled to eliminate the mistakes and abnormalities in depicting particular parts of the balance sheet, which had a considerable impact on the increase of reliability and accuracy of the whole financial revisions of given economic units.

\section{CONCLUSIONS}

Globalisation in the activity of economic units and the dynamically changing surroundings, as well as evolutions caused by the changing law, may cast some doubts if, in the process of fulfilling one's duties when preparing a financial report, there hasn't been omitted or misinterpreted anything that could have any impact on its final form and the assessment of the economic unit and its situation. Conducting the procedures of financial revision while examining the financial report increases the guarantee that the data presented in the report are reliable, clear, credible and reliable. The continuous work of the auditors gives the receivers, not only the outward ones, the sense of credibility that the financial situation of a given economic unit is exactly as presented in the financial report.

To sum up the result of the researches depicted in this article, which are connected with the analysis of the executed changes indicated by the expert auditors after the procedures of financial revision, it can be observed that the study of financial reports in every part of the balance sheet constantly exerts impact on the increase of credibility of financial reports and 
is an inextricable element guaranteeing the proper functioning of the economic subjects on the market in Poland.

\section{REFERENCES}

Andrzejewski, M. (2012). Korygująca funkcja rewizji finansowej w systemie rachunkowości. Kraków: Wydawnictwo Uniwersytetu Ekonomicznego w Krakowie.

Fedak, Z. (2018). Rachunek zysków i strat [w:] Zamknięcie roku 2018. Warszawa: Rachunkowość Sp. z o.o.

Kodeks etyki zawodowych księgowych Międzynarodowej Federacji Księgowych (IFAC), w języku polskim zatwierdzony w roku 2011 przez Międzynarodową Federację Księgowych (IFAC).

Krajowy Standard Rewizji Finansowej 200 w brzmieniu Międzynarodowego Standardu Badania 200 (IAASB) „Ogólne cele niezależnego biegłego rewidenta oraz przeprowadzanie badania zgodnie z międzynarodowymi standardami badania”, Załącznik $\mathrm{nr} 1.1$ do uchwały $\mathrm{Nr}$ 2783/52/2015 Krajowej Rady Biegłych Rewidentów z dnia 10 lutego 2015 r.

Krzywda, D. (2012). The idea, aim and legal bases of revision of financial reports [in:] Krzywda, D., ed., The revision of financial reports. Warsaw: COZS, SKwP.

Lew, G., Nita, B., red. (2015). Propozycja rozszerzenia zakresu opinii i raportu z badania sprawozdania finansowego. „Prace Naukowe Uniwersytetu Ekonomicznego we Wrocławiu”. Wrocław, Wydawnictwo Uniwersytetu Ekonomicznego we Wrocławiu.

Lew, G., Nowak, E., red. (2016). Sporzadzanie sprawozdań finansowych [w:] Rachunkowość. Zasady i metody, Warszawa: PWE.

Nowak, A. (2013). The models of examination of financial reports of enterprises. Warsaw: Wydawnictwo Naukowe PWN.

Pfaff, J. (2008). Wpływ rewizji finansowej na wiarygodność sprawozdania finansowego. Katowice: Wydawnictwo Akademii Ekonomicznej w Katowicach.

Uchwała nr 1554/33a/2017 Krajowej Rady Biegłych Rewidentów z dnia 8 grudnia 2017 r. w sprawie krajowych standardów badania (700 (Z), 701, $705(Z), 706$ (Z), 720 (Z), 260 (Z), $570(\mathrm{Z}))$.

\section{LEGAL ACTS}

Ustawa z dnia 29 września 1994 r. o rachunkowości (tekst jedn. Dz.U. 2019 r., poz. 351).

Ustawa z dnia 11 maja 2017 r. o biegłych rewidentach, firmach audytorskich oraz nadzorze publicznym (Dz.U. z 2017 r., poz. 1089).

DOI: 10.7862/rz.2019.mmr.11

The text was submitted to the editorial office: September 2018.

The text was accepted for publication: June 2019. 